\title{
Effect of Natural Source as Stimulator on Vegetative Growth, Flowering, Chemical Composition and Oil on Viola Odorata, Linn. Mohamed, Safaa. $\mathbf{M}^{1}$.; Abou El-ghit Eman. ${ }^{1}{ }^{1}$; Ghatas, A.A ${ }^{1}$.; Hammam $K^{1}$. Shahin, Aml. A ${ }^{2}$. \\ ${ }^{1}$ Horticulture, Dpt. Fac. Of Agri., Benha University. \\ ${ }^{2}$ Horticulture, Research Institute, Agriculture Research Center.
}

\begin{abstract}
This experiment was carried out during two consecutive seasons of 2016/2017 and 2017/2018 in the experimental field of Fac. of Agriculture Moshtoher, Benha university to study the effect of two forces of magnetic field as $(300,150 \mathrm{mt})$, the distance $(0,30,60,90)$ between magnetic field and plants and their combination on the growth (vegetative, flowering, roots),chemical constituents, oil of Viola odorata L. the treatment of two forces of magnetic field gave significant effect on No. of leaves/plant, leaves area/plant, fresh and dry weight/plant, No. of flower/plant, pedicel length/plant, fresh and dry weight of flower/plant, fresh and dry weight per plant, $\mathrm{N}, \mathrm{P}, \mathrm{K}$ of leaves . The biggest magnetic field (300 Mt) gave the best results. the magnetic field space at zero with plants gave higher significant results in all parameter under this study. The obtained results indicated that the combination between field magnetic at $300 \mathrm{mt}$ with zero instance gave high significant effect for all data recorded.
\end{abstract}

Keywords: viola odorata, magnetic field.

\section{Introduction}

Viola odorata L. known as sweet violet, is considered as rare and endemic perennial plant to Europe and Asia and belongs to the genus viola (MALPIGHIALES: Violaceae) which, includes more than 400 species. is one of the most important medicinal plant used folklore therapy for curing various ailments like bronchitis, common digestive disorders, post-operative tumor metastasis, diabetes and cancer. Phytochemically, different groups of compounds have been isolated from various species of this genus like cyclotides, flavonoids, alkaloids and triterpenoids Darwin (2010). Some of them already have been scientifically accepted as antifungal, antibacterial, anticancer, antioxidant, antiasthmatic, anti-inflammatory, anti-HIV and Over many years, the effects of static magnetic fields on plant life have been the subject of different research studies. Recently, many authors have reported the effects of static magnetic fields on the metabolism and growth of different plant species Numerous experiments have been conducted on the effects of magnetic fields or water exposed to permanent magnets on plant growth M. Rãcuciu1 (2006).

Magnetism is a fundamental property of allnatural materials. The most important kinds of magnetic properties are those called diamagnetism, paramagnetism, ferromagnetism, ferrimagnetism, and super para magnetism. Maher (2008). The use of physical factors for controlling influence on biological behavior during development and storage of different cultures is a modern trend in combining the intensification of plant technologies with the ecological requirements. It could be important for biological and organic agriculture. Physical methods for increasing plant production are based on the use of different physical factors for plant treatment, all living processes are highly dependent on energy exchange between the cell and the environment.

The core of physical methods is the energy supply through the treatment with physical factors Plants sensitivity to the influence of these physical factors has been elaborated during their evolutionary development since these physical factors are elements of their natural environment. The influence of physical factors as the magnetic field is an alternative of soil additives and fertilizers. The substitution of chemical treatment by physical factors can reduce toxins in raw materials and thus - raise food safety. Contemporary agriculture largely uses chemical compounds for improving soil fertility, plant production anantipyretic agents Ebrahimzadeh et al., (2010)

Protection against plant diseases and enemies. The substitution of chemical amelioration with convenient physical methods of treatment has two advantages - one is reducing the use of fertilizers and thus decreasing pollution of on-farm produced raw materials for food production and the other possibility for disinfection of plant before planting and during the storage through inactivation of microorganisms. Anna Aladjadjiyan (2012) for that, the aim ofthis study was to show the possibilities for using a magnet with two forces on the development of Viola odorata L and to determine the best forces of magnetic for the plant.

\section{Material and Methods}

The present study was conducted during two successive seasons of 2016/2017 and 2017/2018 seasons at the Experimental Farm, of the Faculty Agriculture (Moshtoher), Benha University, Egypt. on viola (Viola odorata Linn.). 


\section{A-Plant materials.}

Offsets of violets (Viola odorata Linn.) were obtained from the Horticulture Department, Faculty of Agriculture, Benha University, Egypt. The average plant height was 8 to $10 \mathrm{~cm}$ and the number of leaves was (5-8 leaves).

\section{B-Experimental procedure.}

- The offsets violets were planted: on $22^{\text {th }}$ September 2016 for the first season and $25^{\text {th }}$ September 2017 in the second one.

- The beginning of flowers blooming was, in the first season on the $26^{\text {th }}$ January till $20^{\text {nd }}$ April in the first second season on $7^{\text {st }}$ February till to $24^{\text {th }}$ May.

- $\quad$ There were 5 plots experimental $(100 \mathrm{~cm}$ x100 $\mathrm{cm})$ each plot containing 9 plants. The first plot contained the plants without the magnetic field, the second plot plants at zero distance from the magnetic field, the third plot plants at $30 \mathrm{~cm}$ distance from the magnetic field, the fourth plot plants at $60 \mathrm{~cm}$ distance from the magnetic field, the fifth plot plant at $90 \mathrm{~cm}$ distance from the magnetic field.

The source of magnetic field

- Magnetic field was obtained from Eagle Trading Company) for the trade of screw and steel materials) 33 St- Al - Sabtya- Cairo -Egypt

- $\quad$ Permanent magnet,IS2500 type i3A250 (Manufactured by India Steel Products, Valpaaiso, Indiana)

- The induction of magnetic field has been $B=150$ $\mathrm{mT}$, measured with a digital Tesla meter Systron- Donner. In the Physics Department, Faculty of Science, Cairo University.

- The soil analysis in the present on Table $(1 \mathrm{a}, 1 \mathrm{~b})$ physical and chemical properties of the soil of the experiment were determined at Water and SoilLab. of the Faculty Agriculture (Moshtoher), Benha University, Egypt according to Page $\boldsymbol{e t}$ al., (1982)

Table.1a. Soil mechanical properties.

\begin{tabular}{lllll}
\hline \multirow{2}{*}{ Texture } & \multicolumn{2}{c}{ Sand\% } & \multirow{2}{*}{ Clay \% } & \multirow{2}{*}{ Silt \% } \\
\cline { 2 - 3 } & Fine & Coorse & $\mathbf{5 4 . 5 7}$ & $\mathbf{3 3 . 4 1}$ \\
\hline Clay & 5.59 & 7.43 & .
\end{tabular}

Chemical properties of experimental soil soluble actions and anions mMol/l available (ppm).

Table (1b): Soil chemical properties.

\begin{tabular}{lllllllllllllll}
\hline pH & $\begin{array}{l}\text { E.C } \\
\text { Ds } / m\end{array}$ & So4 $^{--}$ & Cl- & $\mathrm{HCo3}^{-}$ & $\mathrm{Mg}^{++}$ & $\mathrm{Ca}^{++}$ & $\mathrm{K}^{+}$ & $\mathrm{Na}^{+}$ & $\mathrm{N}$ & $\mathrm{P}$ & $\mathrm{K}$ & $\mathrm{Fe}$ & $\mathrm{Mn}$ & $\mathrm{Zn}$ \\
\hline 7.34 & $\mathbf{0 . 6 2}$ & $\mathbf{0 . 8 0}$ & $\mathbf{3 . 4}$ & $\mathbf{2 . 0 0}$ & $\mathbf{1 . 2 0}$ & $\mathbf{2 . 5 0}$ & $\mathbf{1 . 2 3}$ & $\mathbf{1 . 2 7}$ & $\mathbf{9 1 8 . 7}$ & $\mathbf{1 7 . 9}$ & $\mathbf{4 3 1 . 7}$ & $\mathbf{9 4 1 1 . 1}$ & $\mathbf{4 5 0 . 1}$ & $\mathbf{7 2 . 4 3}$ \\
\hline
\end{tabular}

\section{-Chemical fertilizers}

- $\quad$ Nitrogen fertilizer was applied at a rate of $50 \mathrm{~kg}$ $\mathrm{N} /$ fed as ammonium sulphate $\left(\mathrm{SO}_{4}\left(\mathrm{NH}_{3}\right)_{2}, 20.5 \%\right.$ $\mathrm{N})$ was applied at three doses.

- Phosphorus fertilizer was applied at a rate of 25 $\mathrm{kg} \mathrm{P}_{2} \mathrm{O}_{5} /$ feddan as calcium superphosphate $\left(15.5 \% \mathrm{P}_{2} \mathrm{O}_{5}\right)$ was applied at two doses.

- Potassium fertilizer was applied at a rate of 40 $\mathrm{kg} \mathrm{K}_{2} \mathrm{O} /$ feddan as potassium sulphate (48-50 $\left.\mathrm{K}_{2} \mathrm{O} \%\right)$ was applied as one dose at $\left(15 \mathrm{gm} / \mathrm{m}^{2}\right)$ during preparing the soil before planting. according to the recommendations of Agriculture Ministry.

\section{Data recorded:}

\section{- On vegetative growth:}

Vegetative growth parameters were measured at the end of each season, the recorded data included:

1- Number of leaves/ plant

2- Fresh weight of leaves/ plant (gm).

3- Dry weight of leaves / plant (gm).

4- Leaf area $\left(\mathrm{cm}^{2}\right)$. /plant

5- Fresh weight of roots / plant (gm).

6- Dry weight of roots / plant (gm).

\section{- On flowering}

7- Number of flowers / plant.

8- Pedicel length/flower $(\mathrm{cm})$

9- Fresh weight of flowers/ plant (gm).

10- Dry weight of flowers/ plant (gm)

Number of flowers was periodically picked and counted at 15-day interval, therefore total number, fresh weight of flowers /plant, dry weight of flowers /plant were separately calculated per an individual plant.

$>$ Chemical composition:

- Chlorophyll (a and b) contents, (mg/gm FW).

- Nitrogen content in leaves (\% DW).

- Phosphorus content in leaves (\% DW).

- Potassium content in leaves $(\% \mathrm{DW})$.

\section{Chemical determination:}

\section{A- Determination of $\mathrm{N}, \mathrm{P}, \mathrm{K}$ percentage}

The herbs were oven dried at $70^{\circ} \mathrm{C}$ till constant weight then they were ground in willy mill to fin powder, then weighted $0.2 \mathrm{~g}$ of fine powder and it was digested using a mixture of hydrogen peroxide $\left(\mathrm{H}_{2} \mathrm{O}_{2}\right)(4: 10)$, the clear digestion was quantitively to $100 \mathrm{ml}$ volumetric flask in this solution the following elements were determined: 
- $\quad \mathrm{N} \%$ was determined by method as described by Horneck and Miller (1998).

- $\quad \mathrm{P} \%$ was determined by method as described by Hucker and Catroux (1980).

- $\mathrm{K} \%$ was determined by methodas described by Horneck and Hanson (1998).

\section{> Pigments content (mg/g of fresh matter)}

A- Chlorophyll $a, b$ in the fresh leaves

The photosynthetic pigments chlorophyll a, b was extracted by methanol alcohol according to Moron (1982) using the spectrophotometer at wavelength of $656,665 \mathrm{~nm}$, respectively.

\section{$>$ Volatile oil}

Concrete Extraction with Organic Solvents:

- According to Guenther [1961]. Concrete \%of leaves and flowers were extracted by using (nHexane organic).

- Redistilled n-Hexane of a boiling range of 65$70^{\circ} \mathrm{C}$ was used in the preparation of the concrete oil. Violet leaves and flowers were placed in a large glass container and covered with redistilled n-Hexane.

- The mixture put at room temperature for 24 hours.

- After filtration, another quantity of n-Hexane was added to the remaining leaves and flowers for 12 hours.

- By means of a separating funnel. the combined successive n-Hexane extracts were separated from the filtrate (a mixture of $\mathrm{H}_{2} \mathrm{O}$ and nHexane).

- Under reduced pressure and temperature not exceeding $35^{\circ} \mathrm{C}$.The $\mathrm{n}$-Hexane layers were hydrated by over anhydrous sodium sulfate, filtered and evaporated.

- The residue (concrete) is a dark brown, waxy and hard mass.

Volatile Oil Extraction:

- According to Guenther [1961]. we used purified absolute ethyl alcohol to extract the violet volatile oil from the obtained concrete.

- By ethyl alcohol, we shook the residue three times and filtered to leaving the waxy matter.

- The ratio of alcohol to concrete oil was 8:1v/w.

Then filtering at temperature $-15^{\circ} \mathrm{C}$. because the filtrate still contained a small number of waxes which were separated. The filtrate was distilled in vacuo at a temperature not exceeding $35^{\circ} \mathrm{C}$. The residue (volatile oil) is brownish, very viscous or semiliquid oil.

\section{Statistical analysis}

The experimental design was CRD (Complete Randomized Block Design) and the analysis of variance and comparisons between means was done by using the last significant difference (L.S.D) method, according to (Snedecor and Cochranm 1972).

\section{Result and Discussion}

\section{$>$ Plant Growth:}

It is apparent from data in Tables $(2,3,4,5)$ the field magnetic at $300 \mathrm{mt}$ high significant influence the plant growth characters i.e. No. of leaves/plant, the area of leaves/plant $(\mathrm{cm})$, fresh and dry weight of leaves/plant, number of flowers/plants, flower pedicel length/plant, root fresh and dry weight /plant compared to control plant. While the magnetic field at $150 \mathrm{mt}$ gave the next value in this concern.

As for the space between the magnetic field and the plant, zero space gave the best results. The $30 \mathrm{~cm}$, $60 \mathrm{~cm}$ produced the second and third data, respectively. The last result gave by the $90 \mathrm{~cm}$ in space.

Concerning the combination between magnetic field and distance of plants reflected the significant effect on plant growth characters, data in Tables $(2,3,4,5)$ the combination with space zero found significantly superior to the rest of combination treatments regarding plant growth characters in the first and second season Similarly, for chemical content and its oil ratioin Table $(6,7 \mathrm{a}, \mathrm{b}, \mathrm{c}, 8)$. These results were agreed with Sami K et al., (2011), Ran et al., (2009) and Soha E. Khalil and Bedour $\mathbf{H}$. Abou Leila (2016) on Physalis pubescenshe also confirmed that, magnetic treatments positively affected the vegetative growth of plants. plants, which were magnetically treated, had significantly higher plant height, no of branches/plant, no of leaves/plant, root length, leaf area as well as fresh and dry weights of whole plant compared with nonmagnetically treated plants as.

Data observe that most growth and flowering parameters were enhanced So, the stimulative effect of magnetic field on different plant growth characters could be explained by Galland and Pazur (2005) they reported that one of the possible explanations of the observed positive effect of magnetic treatment could be found in paramagnetic properties of some atoms in plant cells and pigments, i.e. chloroplasts. In the outer magnetic field, magnetic moments of these atoms turn to align the field. Magnetic properties of molecules determine their ability to absorb the energy of the magnetic field, then transform it in another kind of energy and transfer this energy later to other structures in plant cells, thus activating them. Magnetic effects on plants can be explained in the framework of the ion cyclotronresonance and the radical pair models, two mechanisms that also play an essential role in the magnetoreception of other organisms, This is also confirmed by Martinez et al., (2009) where they observed that ions in the cell can absorb magnetic energy corresponding to specific parameters related 
to their vibration and rotation energy sublevels. This phenomenon represents a kind of resonance absorption and could explain the stronger effect of applying definite values of magnetic field induction and Occhipintiet al., (2014) informed that, if a magnet was placed below the plants, those containing iron lean towards the ground. However, experiments have proved them wrong. Plants with magnets below them grew taller than those without magnets below them.

On the other hand, Garcia-Reina and Arza (2001) they suggested that the stimulating effect of magnetic treatments on photosynthetic pigments may be due to increasing proline content, which increased some ions as $\mathrm{Mg}_{2}{ }^{+}$needed for chlorophyll synthesis and/or $\mathrm{K}^{+}$which led to increased photosynthetic efficiency possibly by increasing the number of chloroplasts per cell and Waleed et al., (2013) reported that, the magnetic field of 0.5 Tesla resulted in an increase in root length and weight. finely, Neo E. and ED Markus (2018) indicate that, the effects of MF on plants may be dependent on species and/or MF characteristics such as intensity and exposure time.

Table 2. Effect of magnetic (field force and distance) on Viola odoratalinn. during the first and second seasons (2016/2017 and 2017/2018) on Number of leaves/plant and Leaves area/plant/c.m

Number of leaves/ plant

\begin{tabular}{|c|c|c|c|c|c|c|}
\hline \multirow{2}{*}{$\begin{array}{l}\text { season } \\
\text { Force of F.M. }\end{array}$} & \multicolumn{2}{|c|}{ 1 $^{\text {st }}$ season } & \multirow{2}{*}{$\begin{array}{l}\text { M.of } \\
\text { distance }\end{array}$} & \multicolumn{2}{|c|}{$2^{\text {nd }}$ season } & \multirow{2}{*}{$\begin{array}{l}\text { M.of } \\
\text { distance }\end{array}$} \\
\hline & $150 \mathrm{mT}$ & $300 \mathrm{mT}$ & & $150 \mathrm{mT}$ & $300 \mathrm{mT}$ & \\
\hline Control & 70.20 & 69.20 & 69.7 & 73.33 & 71.30 & 72.31 \\
\hline 0 distance & 233.33 & 342.25 & 287.79 & 260.25 & 387.24 & 323.74 \\
\hline 30distance & 201.67 & 289.69 & 245.68 & 240.03 & 330.05 & 285.04 \\
\hline 60distance & 186.25 & 273.28 & 229.76 & 199.12 & 315.92 & 257.52 \\
\hline 90distance & 173.21 & 249.89 & 211.55 & 180.30 & 285.76 & 233.03 \\
\hline M. of force of FM & 198.61 & 288.77 & & 219.92 & 329.97 & \\
\hline
\end{tabular}

L.S.D. for distance at $\mathbf{0 . 0 5 \%}$

2.85

L.S.D. for distance at

L.S.D. for distance at $0.01 \%$

5.07

$\mathbf{0 . 0 5 \%} \quad \mathbf{3 . 1 8}$

L.S. D. for distance at

5.99 $0.01 \%$

\begin{tabular}{|c|c|c|}
\hline L.S.D. for FM at $0.05 \%$ & 3.99 & 4.81 \\
\hline L.S.D. for FM at $0.01 \%$ & 7.01 & 8.76 \\
\hline $\begin{array}{l}\text { L.S.D. for FM*dis. at } \\
\text { 0.05\% }\end{array}$ & 4.09 & \\
\hline L.S.D. for FM*dis. at & 6.60 & 6.71 \\
\hline
\end{tabular}

$0.01 \%$

Leaves area/plant/c.m

\begin{tabular}{|c|c|c|c|c|c|c|}
\hline \multirow{2}{*}{$\begin{array}{l}\text { season } \\
\text { Force of F.M. }\end{array}$} & \multicolumn{2}{|c|}{$1^{\text {st }}$ season } & \multirow{2}{*}{$\begin{array}{l}\text { M.of } \\
\text { distance }\end{array}$} & \multicolumn{2}{|c|}{$2^{\text {nd }}$ season } & \multirow{2}{*}{$\begin{array}{l}\text { M.of } \\
\text { distance }\end{array}$} \\
\hline & $150 \mathrm{mT}$ & $300 \mathrm{mT}$ & & $150 \mathrm{mT}$ & $300 \mathrm{mT}$ & \\
\hline Control & 25.41 & 26.98 & 26.19 & 29.25 & 28.00 & 28.62 \\
\hline 0 distance & 98.91 & 120.25 & 109.58 & 105.62 & 140.04 & 122.83 \\
\hline 30 distance & 84.61 & 105.21 & 94.41 & 96.30 & 121.79 & 109.04 \\
\hline 60 distance & 78.65 & 98.63 & 88.64 & 81.38 & 111.59 & 96.48 \\
\hline 90 distance & 70.92 & 88.36 & 79.64 & 72.05 & 103.76 & 87.90 \\
\hline M. of force of FM & 83.27 & 109.85 & & 88.83 & 119.29 & \\
\hline
\end{tabular}

L.S.D. for distance at $\mathbf{0 . 0 5 \%}$

L.S.D. for distance at $0.01 \%$

L.S. D. for FM at $0.05 \% \quad 2.95$

L.S.D. for FM at $0.01 \% \quad 5.21$

L.S.D. for FM*dis. at $0.05 \%$

3.23

L.S. D. for FM*dis. at $\quad \mathbf{5 . 0 7}$
4.01

L.S.D. for distance at $0.05 \%$

6.13

L.S. D. for distance at $0.01 \%$

4.22

7.09 $0.01 \%$

\subsection{7}

6.41 
Table 3. Effect of magnetic field (field force and distance) onViola odoratalinn. during the first and second seasons (2016/2017 and 2017/2018) on Fresh a dry weight of leaves/plant(g).

\begin{tabular}{|c|c|c|c|c|c|c|}
\hline \multicolumn{7}{|c|}{ Fresh weight of leaves/plant (g) } \\
\hline \multirow{2}{*}{$\begin{array}{l}\text { season } \\
\text { Force of F.M. }\end{array}$} & \multicolumn{2}{|c|}{$1^{\text {st }}$ season } & \multirow{2}{*}{$\begin{array}{l}\text { M. of } \\
\text { distance }\end{array}$} & \multicolumn{2}{|c|}{$2^{\text {nd }}$ season } & \multirow{2}{*}{$\begin{array}{c}\text { M. of } \\
\text { distance }\end{array}$} \\
\hline & $150 \mathrm{mT}$ & $300 \mathrm{mT}$ & & $150 \mathrm{mT}$ & $300 \mathrm{mT}$ & \\
\hline Control & 60.05 & 73.80 & 66.92 & 72.23 & 82.34 & 77.28 \\
\hline 0 distance & 135.29 & 198.35 & 166.82 & 180.72 & 218.90 & 199.81 \\
\hline 30distance & 120.32 & 187.77 & 154.04 & 149.73 & 211.73 & 180.73 \\
\hline 60distance & 101.32 & 168.45 & 134.88 & 130.79 & 187.65 & 159.22 \\
\hline 90distance & 98.22 & 159.36 & 128.79 & 121.03 & 181.20 & 151.11 \\
\hline M. of force of FM & 113.78 & 178.48 & & 145.56 & 199.87 & \\
\hline L.S.D. for distance at $0.05 \%$ & & & \multirow{2}{*}{$\begin{array}{l}4.11 \\
9.67\end{array}$} & \multirow{2}{*}{\multicolumn{2}{|c|}{$\begin{array}{l}\text { L.S.D. for distance at } \\
\text { 0.05\% } \\
\text { L.S.D. for distance at } \\
\text { 0.01\% }\end{array}$}} & 3.11 \\
\hline L.S.D. for distance at $0.01 \%$ & & & & & & 7.31 \\
\hline L.S. D. for FM at $0.05 \%$ & \multicolumn{3}{|l|}{7.98} & \multicolumn{2}{|c|}{3.67} & \\
\hline L.S.D. for FM at $0.01 \%$ & \multicolumn{3}{|l|}{8.05} & \multicolumn{2}{|l|}{6.34} & \\
\hline L.S.D. for FM*dis. at & \multicolumn{2}{|l|}{5.16} & & \multicolumn{2}{|l|}{5.81} & \\
\hline $\mathbf{0 . 0 5 \%}$ & \multicolumn{2}{|l|}{7.97} & & \multirow{2}{*}{\multicolumn{2}{|c|}{7.13}} & \\
\hline \multicolumn{5}{|l|}{$\begin{array}{l}\text { L.S. D. for FM*dis. at } \\
0.01 \%\end{array}$} & & \\
\hline \multicolumn{7}{|l|}{ Dry weight of leaves/plant(g) } \\
\hline season & \multicolumn{2}{|c|}{$1^{\text {st }}$ season } & M.of distance & \multicolumn{2}{|c|}{$2^{\text {nd }}$ season } & M. of \\
\hline Force of F.M. & $150 \mathrm{mT}$ & $300 \mathrm{mT}$ & & $150 \mathrm{mT}$ & $300 \mathrm{mT}$ & distance \\
\hline Control & 24.22 & 30.26 & 27.24 & 30.62 & 35.88 & 33.25 \\
\hline 0 distance & 56.32 & 89.85 & 73.08 & 75.94 & 96.36 & 86.15 \\
\hline 30distance & 50.33 & 81.82 & 66.07 & 62.57 & 90.74 & 76.65 \\
\hline 60distance & 42.39 & 75.30 & 58.84 & 53.62 & 80.57 & 67.09 \\
\hline 90distance & 39.99 & 69.66 & 54.82 & 49.55 & 76.58 & 63.06 \\
\hline M. of force of FM & 47.25 & 79.15 & & 60.42 & 86.06 & \\
\hline L.S.D. for distance at $0.05 \%$ & & & 5.99 & L.S.D. for & tance at & 5.01 \\
\hline L.S.D. for distance at $0.01 \%$ & & & 7.79 & $\begin{array}{r}0.05 \% \\
\text { L.S.D. for } \\
0.01 \% \\
\end{array}$ & stance at & 7.03 \\
\hline L.S. D. for FM at $0.05 \%$ & 6.75 & & & 5.87 & & \\
\hline L.S.D. for FM at $0.01 \%$ & 8.99 & & & 7.92 & & \\
\hline L.S.D. for FM*dis. at & 4.37 & & & 3.99 & & \\
\hline $\begin{array}{l}\text { 0.05\% } \\
\text { L.S. D. for FM*dis. at } \\
\text { 0.01\% }\end{array}$ & 6.14 & & & 6.01 & & \\
\hline
\end{tabular}

Table 4. Effect of magnetic field (force and distance) onViola odoratalinn. during the first and second seasons (2016/2017 and 2017/2018) on Number of flower/plant and Pedicel length of flower(cm).

\begin{tabular}{|c|c|c|c|c|c|c|}
\hline \multicolumn{6}{|c|}{ Number of flower/plants } & \multirow{3}{*}{$\begin{array}{l}\text { M.of } \\
\text { distance }\end{array}$} \\
\hline \multirow{2}{*}{$\begin{array}{l}\text { season } \\
\text { Force of F.M. }\end{array}$} & \multicolumn{2}{|l|}{$1^{\text {st }}$ season } & \multirow{2}{*}{$\begin{array}{l}\text { M.of } \\
\text { distance }\end{array}$} & \multicolumn{2}{|l|}{$2^{\text {nd }}$ season } & \\
\hline & $150 \mathrm{mT}$ & 300mT & & $150 \mathrm{mT}$ & $300 \mathrm{mT}$ & \\
\hline Control & 25.84 & 24.35 & 25.09 & 31.02 & 25.62 & 28.32 \\
\hline 0 distance & 45.97 & 81.43 & 63.7 & 52.95 & 85.41 & 69.18 \\
\hline 30 distance & 44.64 & 78.11 & 61.37 & 56.33 & 83.58 & 70.26 \\
\hline 60 distance & 39.46 & 70.01 & 54.73 & 50.63 & 70.76 & 60.69 \\
\hline 90 distance & 37.60 & 67.80 & 52.7 & 43.51 & 68.75 & 56.13 \\
\hline M. of force of FM & 41.91 & 74.33 & & 50.85 & 77.12 & \\
\hline \multicolumn{3}{|c|}{ L.S.D. for distance at $0.05 \%$} & 2.11 & \multicolumn{2}{|c|}{ L.S.D. for distance at $0.05 \%$} & 2.09 \\
\hline \multicolumn{3}{|c|}{ L.S.D. for distance at $0.01 \%$} & 3.97 & \multicolumn{2}{|c|}{ L.S.D. for distance at $0.01 \%$} & 3.49 \\
\hline L.S. D. for FM at & \multirow{2}{*}{\multicolumn{2}{|c|}{$\begin{array}{l}6.98 \\
9.21\end{array}$}} & & \multicolumn{2}{|c|}{6.07} & \\
\hline $\mathbf{0 . 0 5 \%}$ & & & & 8.79 & & \\
\hline \multicolumn{6}{|l|}{ L.S.D. for FM at } & \\
\hline
\end{tabular}




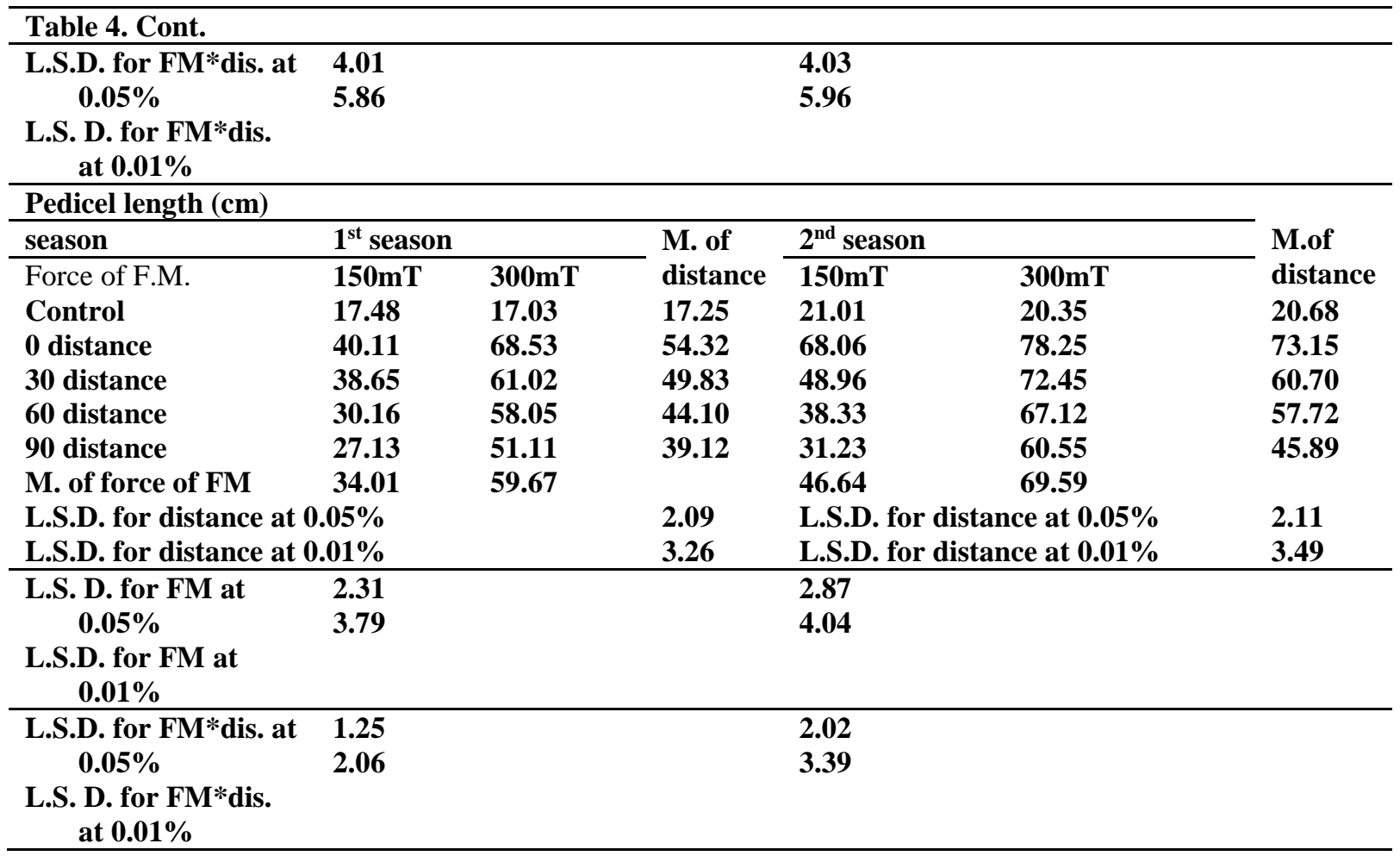

Table 5. Effect of magnetic field (force and distance) onViola odoratalinn. during the first and second seasons (2016/2017 and 2017/2018) Fresh and dry weight of flower/plant(g).

Fresh weight of flower/plant $(g)$

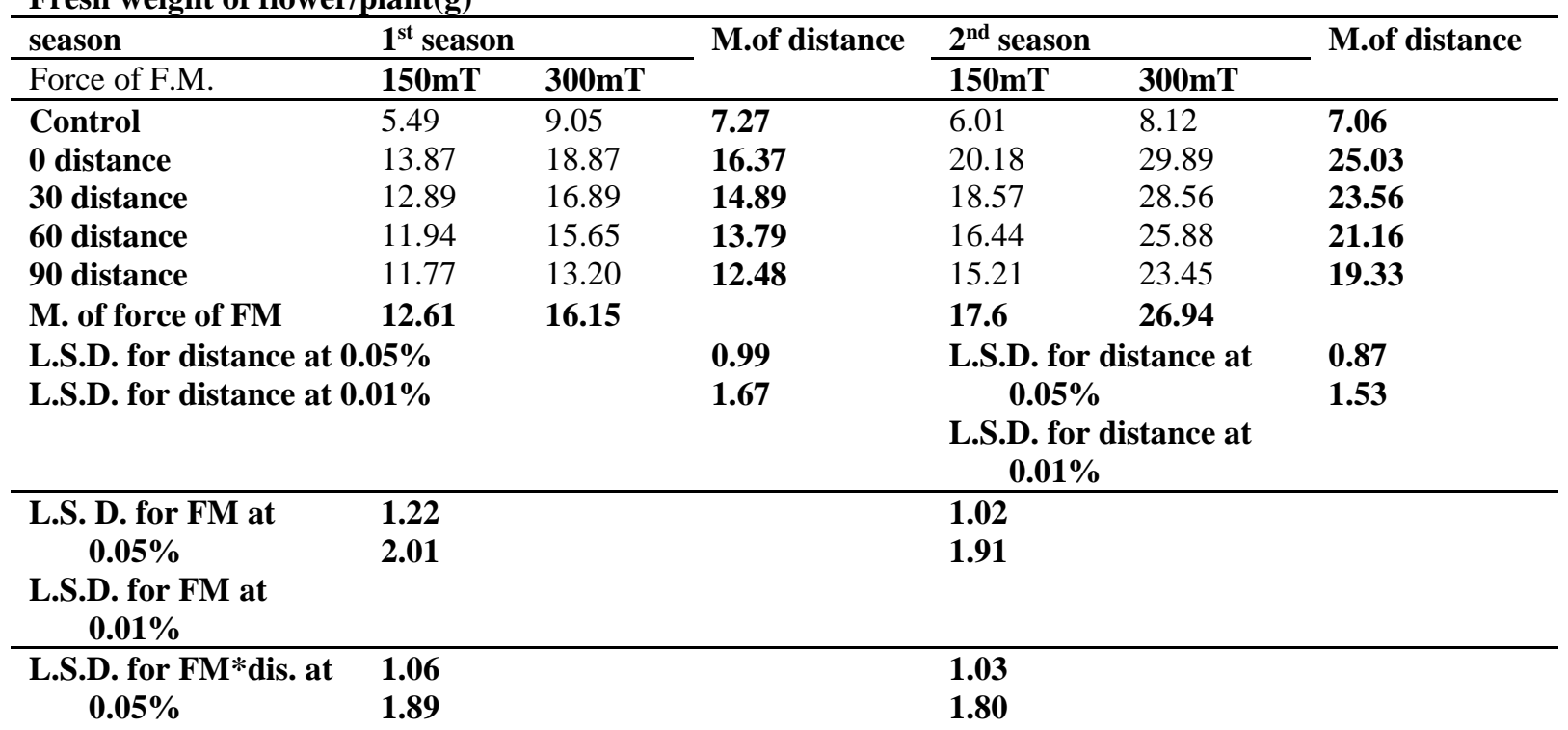

L.S. D. for FM*dis. at $0.01 \%$

\begin{tabular}{|c|c|c|c|c|c|c|}
\hline \multicolumn{6}{|c|}{ Dry weight of flower/ plant(g) } & \multirow{3}{*}{ M. of distance } \\
\hline season & \multicolumn{2}{|c|}{ 1st $^{\text {st }}$ season } & \multirow[t]{2}{*}{ M.of distance } & \multicolumn{2}{|c|}{$2^{\text {nd }}$ season } & \\
\hline Force of F.M. & $150 \mathrm{mT}$ & $300 \mathrm{mT}$ & & $150 \mathrm{mT}$ & $300 \mathrm{mT}$ & \\
\hline Control & 1.44 & 2.65 & 9.23 & 1.58 & 2.28 & 1.93 \\
\hline 0 distance & 4.02 & 10.96 & 7.49 & 6.82 & 17.60 & 12.21 \\
\hline 30 distance & 3.59 & 8.03 & 5.81 & $6 . .18$ & 17.29 & 19.29 \\
\hline 60 distance & 3.54 & 6.98 & 5.11 & 5.71 & 16.03 & 10.87 \\
\hline 90 distance & 2.98 & 4.66 & 3.82 & 4.96 & 14.51 & 9.73 \\
\hline M. of force of FM & 3.53 & 7.65 & & 5.91 & 16.35 & \\
\hline \multirow{2}{*}{\multicolumn{3}{|c|}{$\begin{array}{l}\text { L.S.D. for distance at } 0.05 \% \\
\text { L.S.D. for distance at } 0.01 \%\end{array}$}} & 0.83 & \multirow{2}{*}{\multicolumn{2}{|c|}{$\begin{array}{l}\text { L.S.D. for distance at } 0.05 \% \\
\text { L.S.D. for distance at } 0.01 \%\end{array}$}} & 0.91 \\
\hline & & & 1.01 & & & 1.07 \\
\hline
\end{tabular}




\begin{tabular}{lll}
\hline Table 5. Cont. & & \\
\hline L.S. D. for FM at 0.05\% & 0.62 & 0.71 \\
L.S.D. for FM at 0.01\% & 0.96 & 1.05 \\
L.S.D. for FM*dis. at & 0.97 & 0.87 \\
$\quad$ 0.05\% & 1.23 & 1.23 \\
L.S. D. for FM*dis. at & & \\
$\quad 0.01 \%$ & \\
\hline
\end{tabular}

Table 6. Effect of magnetic field (force and distance)on Viola odoratalinn. plants during the first and second seasons (2016/2017 and 2017/2018) on Fresh and dry weight of roots/plant(g)

Fresh weight of root/plant (g)

\begin{tabular}{|c|c|c|c|c|c|c|}
\hline \multirow{2}{*}{$\begin{array}{l}\text { season } \\
\text { Force of F.M. }\end{array}$} & \multicolumn{2}{|c|}{$1^{\text {st }}$ season } & \multirow{2}{*}{ M. of distance } & \multicolumn{2}{|c|}{$2^{\text {nd }}$ season } & \multirow{2}{*}{ M. of distance } \\
\hline & $150 \mathrm{mT}$ & $300 \mathrm{mT}$ & & $150 \mathrm{mT}$ & $300 \mathrm{mT}$ & \\
\hline Control & 35.38 & 32.21 & 33.79 & 36.25 & 34.94 & 35.5 \\
\hline 0 distance & 120.00 & 171.37 & 145.68 & 135.84 & 193.45 & 164.64 \\
\hline 30distance & 105.92 & 146.55 & 126.23 & 122.51 & 164.46 & 143.48 \\
\hline 60distance & 96.81 & 137.62 & 117.21 & 109.83 & 159.89 & 134.86 \\
\hline 90distance & 85.68 & 124.05 & 126.05 & 93.74 & 140.62 & 117.18 \\
\hline M. of force of FM & 102.10 & 113.89 & & 115.48 & 164.60 & \\
\hline \multicolumn{3}{|c|}{$\begin{array}{l}\text { L.S.D. for distance at } 0.05 \% \\
\text { L.S.D. for distance at } 0.01 \%\end{array}$} & $\begin{array}{l}9.21 \\
10.89\end{array}$ & $\begin{array}{r}\text { L.S.D. f } \\
\text { at } 0 \\
\text { L.S.D. f } \\
\text { at } 0\end{array}$ & $\begin{array}{l}r \text { distance } \\
05 \% \\
r \text { distance } \\
01 \%\end{array}$ & $\begin{array}{l}8.01 \\
10.01\end{array}$ \\
\hline
\end{tabular}

\begin{tabular}{|c|c|c|c|c|c|c|}
\hline $\begin{array}{l}\text { L.S. D. for FM at } \\
\text { 0.05\% } \\
\text { L.S.D. for FM at } \\
\text { 0.01\% }\end{array}$ & \multicolumn{3}{|l|}{11.01} & \multicolumn{2}{|l|}{7.97} & \\
\hline \multicolumn{7}{|l|}{ L.S.D. for FM*dis. at } \\
\hline $\mathbf{0 . 0 5 \%}$ & \multicolumn{3}{|l|}{6.73} & \multicolumn{3}{|l|}{5.79} \\
\hline $\begin{array}{l}\text { L.S. D. for FM*dis. at } \\
\text { 0.01\% }\end{array}$ & \multicolumn{3}{|l|}{8.07} & \multicolumn{3}{|l|}{8.22} \\
\hline \multicolumn{7}{|c|}{ Dry weight of root/plant(g) } \\
\hline Season & \multicolumn{2}{|c|}{$1^{\text {st }}$ season } & $M$ of distonco & \multicolumn{2}{|c|}{$2 n^{d}$ season } & \multirow{2}{*}{ M. of distance } \\
\hline Force of F.M. & $150 \mathrm{mT}$ & 300mT & VI. of aistance & $150 \mathrm{mT}$ & $300 \mathrm{mT}$ & \\
\hline Control & 15.40 & 13.21 & 14.30 & 16.55 & 16.04 & 16.29 \\
\hline 0 distance & 55.14 & 80.18 & 67.66 & 63.56 & 90.16 & 76.86 \\
\hline 30distance & 47.24 & 67.91 & 57.57 & 56.13 & 73.90 & 65.01 \\
\hline 60distance & 44.21 & 63.15 & 53.68 & 50.17 & 69.89 & 60.03 \\
\hline 90distance & 38.07 & 55.34 & 46.70 & 43.18 & 62.50 & 52.84 \\
\hline M. of force of $F M$ & 46.16 & 55.95 & & 53.26 & 74.11 & \\
\hline \multicolumn{3}{|c|}{$\begin{array}{l}\text { L.S.D. for distance at } 0.05 \% \\
\text { L.S.D. for distance at } 0.01 \%\end{array}$} & $\begin{array}{l}3.65 \\
4.99\end{array}$ & $\begin{array}{r}\text { L.S.D. f } \\
\text { at } 0 \\
\text { L.S.D. f } \\
\text { at } 0 \\
\end{array}$ & $\begin{array}{l}\mathrm{r} \text { distance } \\
5 \% \\
\mathrm{r} \text { distance } \\
1 \%\end{array}$ & $\begin{array}{l}3.06 \\
3.97\end{array}$ \\
\hline & \multicolumn{3}{|c|}{ L.S. D. for FM at } & \multicolumn{3}{|l|}{2.99} \\
\hline $\begin{array}{l}\text { L.S.D. for FM at } \\
0.01 \%\end{array}$ & \multicolumn{2}{|l|}{4.14} & & \multicolumn{2}{|l|}{3.65} & \\
\hline \multicolumn{7}{|l|}{ L.S.D. for FM*dis. at } \\
\hline $\begin{array}{l}\text { L.S. D. for FM*dis. at } \\
\text { 0.01\% }\end{array}$ & \multicolumn{2}{|l|}{3.52} & & \multicolumn{2}{|l|}{2.96} & \\
\hline
\end{tabular}


Table 7. Effect of magnetic field (force and distance) on Viola odoratalinn. Plant during the first and second seasons (2016/2017 and 2017/2018) on chlorophyll "a,b" (mg/g.fw)

\begin{tabular}{|c|c|c|c|c|c|c|}
\hline \multicolumn{7}{|c|}{ chlorophyll "a" (mg/g.fw) } \\
\hline season & \multicolumn{2}{|c|}{$1^{\text {st }}$ season } & \multirow{2}{*}{$\begin{array}{l}\text { M. of } \\
\text { distance }\end{array}$} & \multicolumn{2}{|c|}{$2^{\text {nd }}$ season } & \multirow{2}{*}{$\begin{array}{l}\text { M. of } \\
\text { distance }\end{array}$} \\
\hline Force of F.M. & $150 \mathrm{mT}$ & $300 \mathrm{mT}$ & & $150 \mathrm{mT}$ & $300 \mathrm{mT}$ & \\
\hline Control & 1.02 & 1.08 & 1.05 & 1.33 & 1.22 & 1.27 \\
\hline 0 distance & 5.49 & 7.58 & 6.53 & 6.23 & 8.60 & 7.41 \\
\hline 30 distance & 4.61 & 6.97 & 5.79 & 5.50 & 7.37 & 6.43 \\
\hline 60 distance & 3.49 & 6.18 & 4.83 & 4.33 & 7.08 & 5.70 \\
\hline 90 distance & 3.04 & 5.99 & 4.51 & 3.98 & 6.86 & 5.42 \\
\hline M. of force of FM & 4.15 & 6.68 & & 5.01 & 7.47 & \\
\hline L.S.D. for distance at $0.05 \%$ & & & 0.78 & L.S.D. for & ance at $0.05 \%$ & 0.87 \\
\hline L.S.D. for distance at $0.01 \%$ & & & 1.06 & L.S.D. for & ance at $0.01 \%$ & 1.11 \\
\hline L.S. D. for FM at $0.05 \%$ & 0.67 & & & 0.79 & & \\
\hline L.S.D. for FM at $0.01 \%$ & 0.95 & & & 1.02 & & \\
\hline \multicolumn{7}{|l|}{ L.S.D. for FM*dis. At } \\
\hline $\mathbf{0 . 0 5 \%}$ & 0.99 & & & 0.82 & & \\
\hline $\begin{array}{l}\text { L.S. D. for FM*dis. at } \\
\text { 0.01\% }\end{array}$ & 1.26 & & & 1.31 & & \\
\hline \multicolumn{7}{|l|}{ chlorophyll "b"(mg/g.fw) } \\
\hline season & \multicolumn{2}{|c|}{$1^{\text {st }}$ season } & M. of & \multicolumn{2}{|c|}{$2 n^{d}$ season } & \multirow{2}{*}{$\begin{array}{l}\text { M. of } \\
\text { distance }\end{array}$} \\
\hline Force of F.M. & $150 \mathrm{mT}$ & $300 \mathrm{mT}$ & distance & 150m' & $300 \mathrm{mT}$ & \\
\hline Control & 0.70 & 0.68 & 0.69 & 0.70 & 0.78 & 0.74 \\
\hline 0 distance & 3.87 & 4.44 & 4.15 & 4.61 & 5.46 & 5.03 \\
\hline 30distance & 2.53 & 3.91 & 3.22 & 3.42 & 4.31 & 3.86 \\
\hline 60distance & 1.97 & 3.68 & 2.82 & 2.81 & 4.20 & 3.03 \\
\hline 90distance & 1.88 & 3.48 & 2.65 & 2.18 & 3.89 & 3.03 \\
\hline M. of force of FM & 2.56 & 3.87 & & 3.43 & 4.46 & \\
\hline L.S.D. for distance at $0.05 \%$ & & & 0.51 & L.S.D. for & ance at $0.05 \%$ & 0.43 \\
\hline L.S.D. for distance at $0.01 \%$ & & & 0.89 & L.S.D. for & ance at $0.01 \%$ & 0.72 \\
\hline L.S. D. for FM at $0.05 \%$ & 0.32 & & & 0.29 & & \\
\hline L.S.D. for FM at $0.01 \%$ & 0.60 & & & $\mathbf{0 . 5 8}$ & & \\
\hline L.S.D. for FM*dis. at & & & & & & \\
\hline $\begin{array}{l}\quad 0.05 \% \\
\text { L.S. D. for FM*dis. at }\end{array}$ & $\begin{array}{l}0.29 \\
0.47\end{array}$ & & & $\begin{array}{l}0.30 \\
0.39\end{array}$ & & \\
\hline $0.01 \%$ & & & & & & \\
\hline
\end{tabular}

Table 7a. . Effect of magnetic field (force and distance) on Viola odoratalinn. plant during the first and second seasons (2016/2017 and 2017/2018) on Nitrogen\%

\begin{tabular}{|c|c|c|c|c|c|c|}
\hline \multicolumn{6}{|l|}{ Nitrogen $\%$} & \multirow{3}{*}{$\begin{array}{l}\text { M.of } \\
\text { distance }\end{array}$} \\
\hline season & \multicolumn{2}{|c|}{ 1st $^{\text {st }}$ season } & \multirow{2}{*}{$\begin{array}{l}\text { M.of } \\
\text { distance }\end{array}$} & \multicolumn{2}{|c|}{$2 n^{d}$ season } & \\
\hline Force of F.M. & $150 \mathrm{mT}$ & $300 \mathrm{mT}$ & & $150 \mathrm{mT}$ & $300 \mathrm{mT}$ & \\
\hline Control & 0.67 & 0.65 & .66 & 0.71 & 0.68 & 0.69 \\
\hline 0 distance & 3.96 & 5.82 & 4.89 & 4.00 & 6.72 & 5.36 \\
\hline 30distance & 2.94 & 4.88 & 3.91 & 3.33 & 5.60 & 4.46 \\
\hline 60distance & 2.57 & 4.30 & 3.43 & 3.01 & 5.23 & 4.12 \\
\hline 90distance & 2.23 & 3.85 & 3.04 & 2.88 & 4.75 & 3.81 \\
\hline M. of force of FM & 2.92 & 4.71 & & 3.30 & 5.57 & \\
\hline \multirow{2}{*}{\multicolumn{3}{|c|}{$\begin{array}{l}\text { L.S.D. for distance at } 0.05 \% \\
\text { L.S.D. for distance at } 0.01 \% \\
\end{array}$}} & 0.25 & \multirow{2}{*}{\multicolumn{2}{|c|}{$\begin{array}{l}\text { L.S.D. for distance at } 0.05 \% \\
\text { L.S.D. for distance at } 0.01 \%\end{array}$}} & 0.29 \\
\hline & & & 0.42 & & & 0.47 \\
\hline L.S. D. for FM at & \multirow{2}{*}{\multicolumn{2}{|c|}{$\begin{array}{l}0.21 \\
0.37\end{array}$}} & & \multicolumn{2}{|c|}{0.26} & \\
\hline $0.05 \%$ & & & & 0.41 & & \\
\hline \multicolumn{7}{|l|}{ L.S.D. for FM at $0.01 \%$} \\
\hline L.S.D. for FM*dis. at & \multirow{2}{*}{\multicolumn{2}{|c|}{$\begin{array}{l}0.19 \\
0.26\end{array}$}} & & \multicolumn{2}{|l|}{0.20} & \\
\hline $0.05 \%$ & & & & \multicolumn{2}{|l|}{0.28} & \\
\hline \multicolumn{3}{|l|}{ L.S. D. for FM*dis. at } & & & & \\
\hline
\end{tabular}


Table 7b. Effect of magnetic field (force and distance) on Viola odoratalinn. plant during the first and second seasons (2016/2017 and 2017/2018) on Phosphorus\%.

\begin{tabular}{|c|c|c|c|c|c|c|}
\hline \multicolumn{6}{|l|}{ Phosphorus\% } & \multirow{3}{*}{$\begin{array}{l}\text { M.of } \\
\text { dist } \\
\text { anc } \\
\text { e }\end{array}$} \\
\hline season & $1^{\text {st }}$ seaso & & \multirow{2}{*}{$\begin{array}{l}\text { M.of } \\
\text { dist } \\
\text { anc } \\
\text { e }\end{array}$} & \multicolumn{2}{|c|}{$2^{\text {nd }}$ season } & \\
\hline Force of F.M. & $150 \mathrm{mT}$ & $300 \mathrm{mT}$ & & $150 \mathrm{mT}$ & $300 \mathrm{mT}$ & \\
\hline Control & 0.25 & 0.22 & 0.23 & 0.28 & 0.27 & 0.27 \\
\hline 0 distance & 3.50 & 5.38 & 4.44 & 3.59 & 6.28 & 4.93 \\
\hline 30distance & 2.50 & 4.44 & 3.47 & 2.90 & 5.18 & 4.04 \\
\hline 60distance & 2.13 & 3.85 & 2.99 & 2.58 & 4.80 & 3.69 \\
\hline 90distance & 1.80 & 3.39 & 2.59 & 2.38 & 4.23 & 3.30 \\
\hline M. of force of FM & 2.48 & 4.26 & & 2.86 & 5.12 & \\
\hline \multicolumn{3}{|c|}{$\begin{array}{l}\text { L.S.D. for distance at } 0.05 \% \\
\text { L.S.D. for distance at } 0.01 \%\end{array}$} & $\begin{array}{l}0.14 \\
0.23\end{array}$ & \multicolumn{2}{|c|}{$\begin{array}{l}\text { L.S.D. for distance at } 0.05 \% \\
\text { L.S.D. for distance at } 0.01 \%\end{array}$} & $\begin{array}{l}0.12 \\
0.21\end{array}$ \\
\hline $\begin{array}{l}\text { L.S. D. for FM at } \\
\text { 0.05\% } \\
\text { L.S.D. for FM at } \\
\text { 0.01\% }\end{array}$ & $\begin{array}{l}0.11 \\
0.21\end{array}$ & & & \multicolumn{2}{|l|}{0.18} & \\
\hline $\begin{array}{l}\text { L.S.D. for FM*dis. at } \\
\text { 0.05\% } \\
\text { L.S. D. for FM*dis. at } \\
\text { 0.01\% }\end{array}$ & $\begin{array}{l}0.18 \\
0.25\end{array}$ & & & \multicolumn{2}{|l|}{$\begin{array}{l}0.13 \\
0.22\end{array}$} & \\
\hline
\end{tabular}

Table 7c. Effect of magnetic field (force and distance) on Viola odoratalinn. plantsduring the first and second seasons (2016/2017 and 2017/2018) on Potassium \%

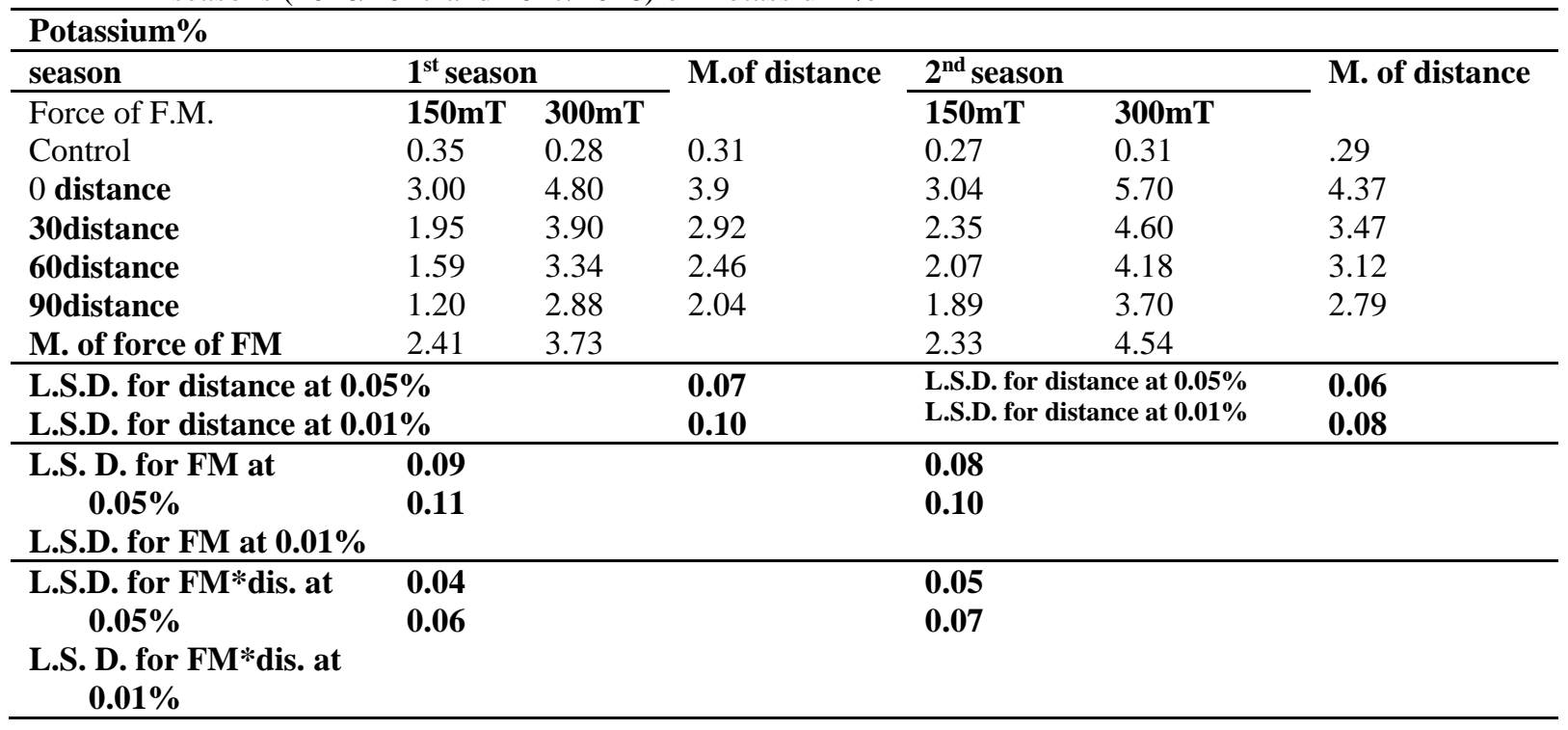

Table 8. Effect of magnetic field on Viola odoratalinn. plant during the first and second seasons (2016/2017 and 2017/2018) on flowers and leaves concrete\%

\begin{tabular}{|c|c|c|c|c|c|c|}
\hline \multicolumn{7}{|l|}{ Flowers concrete\% } \\
\hline \multirow{2}{*}{$\begin{array}{l}\text { Season } \\
\text { force of F.M. }\end{array}$} & \multicolumn{2}{|c|}{$1^{\text {st }}$ season } & \multirow{2}{*}{ M.of distance } & \multicolumn{2}{|c|}{$2 n^{d} \operatorname{season}$} & \multirow{2}{*}{ M.of distance } \\
\hline & $150 \mathrm{mT}$ & $300 \mathrm{mT}$ & & $150 \mathrm{mT}$ & $300 \mathrm{mT}$ & \\
\hline Control & 0.069 & 0.069 & 0.069 & 0.068 & 0.071 & 0.069 \\
\hline 0 distance & 0.160 & 0.265 & 0.212 & 0.178 & 0.288 & 0.233 \\
\hline 30 distance & 0.149 & 0.234 & 0.191 & 0.159 & 0.250 & 0.204 \\
\hline 60 distance & 0.130 & 0.222 & 0.176 & 0.141 & 0.231 & 0.186 \\
\hline 90 distance & 0.128 & 0.198 & 0.163 & 0.131 & 0.225 & 0.178 \\
\hline M. of force of FM & 0.127 & 0.197 & & 0.135 & 0.213 & \\
\hline
\end{tabular}


Table 8. Cont.

\begin{tabular}{|c|c|c|c|c|c|c|}
\hline \multirow{2}{*}{$\begin{array}{l}\text { Leaves concrete\% } \\
\text { season } \\
\text { Force of F.M. }\end{array}$} & \multicolumn{2}{|l|}{$1^{\text {st }}$ season } & \multirow[t]{2}{*}{ M.of distance } & \multicolumn{2}{|l|}{$2^{\text {nd }}$ season } & \multirow[t]{2}{*}{ M.of distance } \\
\hline & $150 \mathrm{mT}$ & $300 \mathrm{mT}$ & & $150 \mathrm{mT}$ & $300 \mathrm{mT}$ & \\
\hline Control & 0.056 & 0.055 & 0.055 & 0.061 & 0.059 & 2.27 \\
\hline 0 distance & 0.130 & 0.198 & 0.164 & 0.149 & 0.219 & 0.184 \\
\hline 30 distance & 0.118 & 0.176 & 0.147 & 0.132 & 0.193 & 0.162 \\
\hline 60 distance & 0.109 & 0.145 & 0.127 & 0.115 & 0.159 & 0.137 \\
\hline 90 distance & 0.098 & 0.131 & 0.114 & 0.106 & 0.140 & 0.123 \\
\hline M. of force of FM & 0.102 & 0.141 & & 0.112 & 0.154 & \\
\hline
\end{tabular}

\section{References}

Anna Aladjadjiyan (2012). Physical Factors for Plant Growth Stimulation Improve Food Quality, Food Production - Approaches, Challenges and Tasks, Prof. Anna Aladjadjiyan (Ed.), ISBN: 978953-307-887-8-

Darwin DM (2010). Anticancer and chemosensitizing abilities of cycloviolacin 02 from Viola odorata and psyle cyclotides from Psychotrialeptothyrsa. Biopoly 40: $617-25$.

Ebrahim. zadeh .MA, Nabavi S f, Nabavi S M, Eslami B (2010). Antioxidant and free radical scavenging activity of $H$. officinalis $L$. var. angustifolius, V. odorata, B. hyrcana and C. speciosum. Pak J Pharm Sci 23(1): 29-34.

Galland, P. and Pazur, A (2005) Magnetoreception in plants.j plant res. 118:371-389.

Garcia-Reina F, Arza PL (2001) Influence of a stationary magnetic field on water relations in lettuce seeds. Part I: Theoretical considerations, Bio electromagnetics 22:589-595.

Guenther, E., (1961) The Essential Oils. Vol.(1v). van Nostrand co. New York

Herbert, D., P.J. Phipps and R.E. Strange, (1971). Determination of Total Carbohydrates. Methods in Microbiology, 5(8): 290-

Horneck, D.A. and D. Hanson,(1998)Determinationof Potassium and Sodium by Flame EmissionSpectrophotometry. In hand book of referencemethods for plant analysis, Kolra, Y.P. (ed). 153-155.

Hucker, T. and G. Catroux, (1980)Phosphorus insewage ridge and animal's wastes slurries.Proceeding of the EEC Seminar, Haren (Gr):

M. Rãcuciu1, D. Creangã2, I. Horga3(2006) plant growth under static magnetic field influence $\square$ rom. journ. phys., vol. 53, nos. 1-2, p. 353-359.

Maher, B. A. (2008) Environmental magnetism and climate change. Contemporary Physics, 48, 247274.

Martnez, E., Flrez, M., Maqueda, R., Carbonell, M.V. \& Amaya, J.M. (2009). Pea (Pisum sativum, L.) and lentil (Lens culinaris, Med.) growth stimulation due t exposure to 125 and 250 mT stationary fields. Polish Journal of Environmental Studies, vol.18, No.4, pp.657-663.

Moran, R., (1982). Formulae for determination of achlorophyllous pigments extractedwith $N, N$ dimethylformamide. Plant Physiol. 69, 13761381

Neo E. Nyakane and ED Markus (2018) The effects of magnetic fields on plants growth: A comprehensive review. Researchgate.net.

Occhipinti, A., De Santis, A., and Maffei, M. E. (2014). Magnetoreception: an unavoidable step for plant evolution? Trends Plant Sci. 19, 1-4. doi: 10.1016/j.tplants.2013.10.007

Page, A.L., R. Miller and H. Keeney, (1982.) Methodsof Soil Analysis. Part 2, $2^{\text {nd }}$ Ed., Am. Soc. Agronomy,Inc. Mad. Wisconsin, USA.

Ran C. Hongwei, Y. Jinsong, $H$ and Wanpeng, $Z$. (2009)The effects of magnetic fields on water molecular hydrogen bonds. Journal of molecular structure, 938: 15-19.

Sami Kz M. Ameen Nasreen K. Aziz Nawal M. Alwan (2011) Effect of magnetized water with different magnetic fields and foliar spray of benzyl adenin on growth and flowering of Rosa Damascena mill. Tikrit university journal of agricultural sciences volume 11, no. 2 .

Snedecor, G.W. and W.G. Cochran, (1989). Statistical Methods. 8th Ed. Iowa State Univ. Press, Ames Iowa, USA.

Soha E. Khalil and Bedour H. Abou Leila (2016) Effect of Magnetic treatment in improving Growth, Yield and fruit quality of Physalis pubescens plant grown under saline irrigation conditions. IJCRGG, ISSN: 0974-4290, Vol.9, No.12 pp 246-258.

Waleed, A., Jabail, Riyadh, C.H., Abul, H. and Hussein, F. (2013) Effect of magnetic field on seed germination of Triticum Aestivum. world journal agricultural sciences. 1(5): 168-171. 